The University of San Francisco

USF Scholarship: a digital repository@ Gleeson Library |

Geschke Center

2014

\title{
The Impact of New, Renewal and Termination Sponsorship Announcements on Share Price Returns
}

\section{T. S. Kruger}

Michael M. Goldman

University of San Francisco, mmgoldman@usfca.edu

M. Ward

Follow this and additional works at: http://repository.usfca.edu/sm

Part of the Sports Management Commons

\section{Recommended Citation}

Kruger, T. S., Goldman, M. M., \& Ward, M. (2014). The impact of new, renewal and termination sponsorship announcements on share price returns. International Journal of Sport Marketing \& Sponsorship, 15(4), 223-238. https://doi.org/10.1108/

IJSMS-15-04-2014-B003 
The impact of new, renewal and termination sponsorship announcements on share price returns

Thomas S. Kruger

Post-graduate student, Gordon Institute of Business Science, University of Pretoria

Tel: +27-11-631-4570

E-mail: thomas.kruger@standardbank.co.za

Michael M. Goldman*

Senior Lecturer, Gordon Institute of Business Science, University of Pretoria \& Assistant

Professor, University of San Francisco

Tel: +27-11-771-4000

E-mail: goldmanm@gibs.co.za

Mike Ward

Chair of Finance, Gordon Institute of Business Science, University of Pretoria

Tel: +27-11-7714000

E-mail: wardm@gibs.co.za

* Author for correspondence

Thomas S. Kruger is a Financial Services professional at Standard Bank South Africa in Johannesburg.

Michael M. Goldman is a Senior Lecturer at the Gordon Institute of Business Science in Johannesburg and an Assistant Professor at the University of San Francisco, where his interests include sport marketing and sponsorship.

Mike Ward is the Chair of Finance at the Gordon Institute of Business Science in Johannesburg where he teaches and consults widely in corporate finance and financial strategy. 


\title{
The impact of new, renewal and termination sponsorship announcements on share price returns
}

\begin{abstract}
What impact do sport sponsorship announcements have on the share price returns of the sponsoring firms? The purpose of this research is to examine the impact of new, renewal and termination sponsorship announcements on share price returns. The research employed the widely acceptable event study methodology to analyse 118 announcements made by 19 firms over a period of more than 11 years. The mixed findings across all three announcement types point to the lack of consideration given to the sponsorship investment by investors. The findings suggest that, although some firms may position their sponsorships as a contributor towards competitive advantage, the announcements of sport sponsorships are not always taken into account by the market. The discussion of findings also highlights two alternate explanations for our findings, including that investors evaluated sponsorship contracts as achieving marketclearing prices, and that the size or importance of sponsorship contracts relative to other investments made by the sponsoring firms was not significant enough to result in investors buying or selling shares. The study concludes with recommendations for managers, as well as suggestions for further research.
\end{abstract}

\section{Executive summary}

During 2010, global sponsorship expenditure on athletes, teams and facilities grew to US\$46.3 billion, with growth forecast at over 5\% for 2011 (IEG, 2011). Sport sponsorship has attracted an increased share of marketing investment, with growing evidence of the positive returns generated for the participating brands and businesses (Cornwell, 2008). Given the extent of financial resources allocated to sport sponsorships, researchers have increasingly questioned the relationship between sponsorship announcements and share price returns. Positive abnormal share price gains have been used to indicate that the market viewed the announcement favourably, while abnormal share price losses may point to the opposite outcome (Clark, Cornwell, \& Pruitt, 2009; Kim \& Morris, 2003). Previous findings, however, have been 
contradictory (Pruitt, Cornwell \& Clark, 2004; Lei, Gosh \& Srinivasan, 2010; Clark, Cornwell \& Pruitt, 2009; Ozturk, Kozub \& Kocak, 2004), providing limited guidance on this relationship. Although the impact of sponsorship announcements on share price movements has received some attention, further research related to new, repeat and termination announcements is needed (Cornwell, 2008; Johnston, 2010). In addition to the contradictory findings thus far, the vast majority of studies have taken place in developed economies in North America and Europe. Sport sponsorship announcements by firms in emerging and other markets have received very little attention. The impact of sponsorship announcements on firms listed on Stock Exchanges other than the NYSE may contribute to a fuller understanding of the impact of sponsorship on shareholder wealth (Jensen \& Hsu, 2011).

The purpose of this research is to examine the impact of new, renewal and termination sponsorship announcements on share price returns. Previous findings are used to hypothesise that new sponsorship announcements will result in a positive share price return of the sponsoring firm, while announcements of sponsorship renewals or terminations will result in a negative share price return of the sponsoring firm. The research employs the widely acceptable event study methodology to analyse 118 announcements made by 19 firms over a period of more than 11 years.

The data and our subsequent analysis found no significant share price increases or decreases for new and termination sponsorship announcements. The findings demonstrated a short-term increase of $4.35 \%$ for renewal announcements. The results indicate that the sponsorship announcements had limited effect on share price abnormal returns after the announcement date. These findings provide further caution to the accepted view that the marketplace sees sponsorships as a good investment (Cornwell, Pruitt \& Clark, 2005).

Amis, Slack and Berrett (1999) argued that a sport sponsorship should be assessed in terms of its potential to contribute to a position of competitive advantage for the firm. The authors recommended that achieving this would require committing time, effort and resources to it, similar to other investments that are expected to generate positive future shareholder wealth. Our findings suggest that, although some firms may position their sponsorships as a contributor towards competitive advantage, the announcements of sport sponsorships are not always taken into account by the market. The discussion of findings also highlights two alternate explanations for our findings, including that investors evaluated sponsorship contracts as achieving market- 
clearing prices, and that the size or importance of sponsorship contracts relative to other investments made by the sponsoring firms was not significant enough to result in investors buying or selling shares. We conclude the study with recommendations for managers, as well as suggestions for further research.

\section{Introduction}

Sport sponsorship investments continue to grow, resulting in a greater focus on their impact on firm performance. During 2010, global sponsorship expenditure on athletes, teams and facilities grew to US\$46.3 billion, with growth forecast at over 5\% for 2011 (IEG, 2011). As a marketing investment, sport sponsorship has attracted an increased share, with growing evidence of the positive returns generated for the participating brands and businesses (Cornwell, 2008; Roy \& Cornwell, 2003; Smolianov \& Shilbury, 2005). Commenting on the renewal of Vodafone's US\$75 million a year sponsorship of McLaren Mercedes, Daragh Persse, Vodafone's global head of sponsorship, cause marketing and media, stated that:

"Our sponsorships are selected on merit of delivery against meeting our current business objectives and ensuring an acceptable return on investment. We strongly believe in the power of sponsorship as a way to help build our brand, delight customers and drive revenue. Sponsorship remains a critical element of brand-building activities, particularly in an environment where customers' consumption of media has become increasingly fragmented" (Formula1.com, 2010).

Given the extent of the financial resources allocated to sport sponsorships, and the oft-seen additional spend on leveraging sponsorship marketing rights, researchers have increasingly questioned the impact of sponsorships on shareholder wealth. One stream of research in this regard has explored the relationship between sponsorship announcements and share price returns. A review of the findings over the past decade suggests that the impact of sponsorship announcements is contradictory. Although sponsorship announcements can communicate firsttime, renewal and termination decisions, research has thus far only considered the impact of new 
and renewal announcements. No research has to date investigated the impact of all announcement types on share price movements.

In addition to the contradictory findings thus far, the vast majority of studies have taken place in developed economies in North America and Europe. Sport sponsorship announcements by firms in emerging and other markets have received very little attention. Analysis of Heineken's $€ 20$ million renewal of its UEFA Champions League sponsorship, MTN's US\$65 million new sponsorship of the FIFA World Cup, or SABMiller's US\$9.4 million renewal of its Cricket South Africa sponsorship have not been considered in previous research. The impact of sponsorship announcements on firms listed on Stock Exchanges other than the NYSE may contribute to a fuller understanding of the impact of sponsorship on shareholder wealth (Jensen \& Hsu, 2011).

\section{Theoretical framework and hypotheses}

Kim (2010) suggested that marketers are now examining the effect of sport sponsorship in terms of either consumer psychology or financial perspectives, including stock market returns. Daellenbach, Davies and Ashill (2006, p. 73) highlighted the shift that has taken place within sponsorship from a "philanthropic activity conducted at the whim of the CEO" to a "highly integrated market-oriented activity". Sport sponsorship can thus be employed by a firm to enhance customer acquisition, growth and retention, thereby also signalling improved financial prospects to current and potential investors. Most recently, Jensen and Hsu (2011) demonstrated how firms that consistently invest in sponsorship outperformed market averages, while those sponsors who spent at an above-average level outperformed those who spent at a below-average level.

A growing number of researchers have investigated the relationship between sport sponsorship and shareholder wealth through the impact of sponsorship announcements on share price movements (Clark, Cornwell \& Pruitt, 2002, 2009; Cornwell, Pruitt, \& Clark, 2005; Johnston, 2010; Kim, 2010; Lei, Ghosh, \& Srinivasan, 2010; Mishra, Bobinski, \& Bhabra, 1997; Miyazaki \& Morgan, 2001; Pruitt, Cornwell \& Clark, 2004; Spais \& Filis, 2008). Positive abnormal share price gains have been used to indicate that the market viewed the announcement 
favourably, while abnormal share price losses may point to the opposite outcome (Clark, Cornwell, \& Pruitt, 2009; Kim \& Morris, 2003).

Clark, Cornwell and Pruitt (2002) provided evidence of the positive share price impact of 49 first time stadium naming rights sponsorships in the USA between 1985 and 2000. Their finding of upward shifts in shareholder value was especially applicable to smaller firms in their sample, which were local firms that had announced longer deals. Becker-Olsen (2003) also found a significant positive impact over a five-day period around the announcement for 39 stadium naming rights sponsorships studied. Cornwell, Pruitt and Clark (2005) reported similar positive impact findings in their study of 53 official product sponsors, while Pruitt, Cornwell and Clark (2004) found mean increases in shareholder wealth of over US\$300 million among the 24 NASCAR sponsors in their analysis. More recently, Lei, Gosh and Srinivasan (2010) focused on the longer term and more strategic partnership form of sponsorship in their study of 85 first time announcements. The authors also found a positive share price impact for their 14-year USA sample.

Although the evidence supporting positive share price impacts is growing, it has not been conclusive. Ozturk, Kozub and Kocak (2004) found no difference in share price movements among 16 Paralympics sponsors in the USA and their relevant competitor set. Clark, Cornwell and Pruitt's (2009) analysis of 114 announcements in the USA also found no overall impact on shareholder wealth of first time announcements. In their study of the impact of the announcement of the $€ 33$ million sponsorship contract between Juventus Football Club and Fiat, Spais and Filis (2008) reported a negative impact on the Juventus share price and a positive impact for Fiat. Given the broadly positive, yet mixed, evidence available, we expect a positive market reaction to first time announcements of sport partnerships. Hence, we arrive at our first hypothesis:

Hypothesis 1: Announcements regarding first time sponsorships will result in a positive share price reaction for the sponsoring firm.

Although sponsorship duration is seen as important to the success of sponsorships (Clark, Cornwell \& Pruitt, 2009; Crimmins \& Horn, 1996), surprisingly few studies have investigated the impact of sponsorship renewal announcements on shareholder wealth. In their partnership- 
focused research, Lei, Gosh and Srinivasan (2010) analysed 29 renewal announcements, drawn from a period of 18 years. The findings suggested a negative impact on shareholder wealth, with the authors pointing to possible investor perceptions of management decision-making driven more by personal benefit and relationships than investment returns. Clark, Cornwell and Pruitt (2009) reported mixed findings in their study of title sponsorship renewals. For the NASCAR "phenomenon" (p. 179) announcements, the authors found a positive share price impact after renewal announcements. No impact was found for the NCAA renewal announcements and a strong negative impact of $-3 \%$ was reported for the PGA renewal announcements. Clark, Cornwell and Pruitt (2009) suggested that their neutral and negative results were due to rights fee escalations and market competition.

The extant research on the "unexplored issue" (Lei, Gosh \& Srinivasan, 2010, p. 729) of renewal announcements provides limited guidance. The influence of negative investor perceptions of management motives, as well as market competition, both evident in the South African sponsorship environment (Gumede, 2011; Scarcella, 2010), suggest that we can expect a negative market reaction to renewal announcements of sport sponsorships. Hence we developed our second hypothesis as:

Hypothesis 2: The announcement of a sponsorship renewal will result in a negative share price reaction for the sponsoring firm.

The termination of sport sponsorships has been referred to by a number of authors (Copeland, Frisby \& McCarville, 1996; Li, Sparks \& Young, 2008), although no studies have thus far investigated the impact termination announcements have on shareholder wealth. A positive market response may result from investors viewing management's decision as a well-considered redirection of limited resources to higher-return investments, such as employee training, quality improvements or more intensive distribution. Previous research has found that the most frequently cited reasons for nonrenewal were an evaluation of inadequate returns, nonachievement of corporate objectives, and changing corporate objectives. In this way, the sponsorship termination may provide access to more promising alternatives.

A negative market response to a termination announcement may result from an acknowledgement that "clearly and formally articulated" (Farrelly, 2010, p. 324) expectations 
related to the strategic value of the sponsorship were lacking from the beginning, raising questions about the quality of firm management. Withdrawing from a long-held sponsorship due to regulatory pressure (Mason \& Cochetel, 2006) or reduced marketing budgets (Orphanides, 2010) may also signal more modest future cash flow expectations. Hence, we defined our third hypothesis as:

Hypothesis 3: The announcement of a sponsorship termination will result in a negative share price reaction for the sponsoring firm.

Although the impact of sponsorship announcements on share price movements has received some attention, further research related to new, repeat and termination announcements is needed (Cornwell, 2008; Johnston, 2010).

\section{Methodology}

Researchers have employed event study methodology as a useful approach to investigate change in a share price that occurs as a result of an unanticipated firm announcement (McWilliams \& Siegel, 1997; Johnston, 2010). Investors fully and accurately incorporate any new or unexpected information that has value relevance into the share price, specifically for the market efficiency hypothesis in finance (Fama, 1991). Event study methodology is widely accepted as a research tool in finance and economic disciplines, and is also used in marketing research (Miyazaki \& Morgan, 2001). Any public announcement constitutes information regarding the present and future marketing strategy of the firm and holds potential value for the investment marketplace. A company's decision to invest or divest in marketing communications by means of sponsorship, may flow directly from the strategy the company is following. This methodology therefore captures the market's valuation of a management decision by measuring the abnormal returns associated with the announcement of that strategy (Filbeck, Zhao, Tompkins, \& Chong, 2009). A share price's abnormal return has been shown to provide an unbiased estimate of the economic worth of the sponsorship investment or event (Kim, 2010).

Theoretical sampling was applied to extract a sample of 118 sport sponsorship announcements made by 19 firms over a period of more than 11 years (see Appendix 1). To be 
included in the sample, sponsoring firms had to meet two screening criteria. First, their shares had to trade on the Johannesburg Stock Exchange (JSE) Main Board, the JSE Africa Board or the JSE AltX, and second, their daily share market prices had to be available from the McGregor BFA market share price database. The 125 -year old JSE is among the world's $20^{\text {th }}$ largest stock exchanges with over 400 listed companies, 358 of which are domestic companies. As an emerging market and recently invited member of the BRICS Forum, South Africa is becoming increasingly important in the global sports industry (Goldman, 2011). South Africa is ranked the $14^{\text {th }}$ largest sponsorship market globally and the largest in Africa (Sports Marketing Frontiers, 2011).

Following the precautions recommended for conducting event studies (McWilliams \& Siegel, 1997; Johnston, 2010), sponsorship announcements that competed with other corporate announcements appearing in the same week by the same firm, such as mergers and acquisition announcements that could influence the share price abnormal return during the event window, were eliminated as confounding. A number of company and sport marketing websites were used to extract sponsorship announcement details. As per Cornwell, Pruitt and Clark (2005), care was taken to determine the date of the first sponsorship communications.

To analyse the data we used an event study analysis, for which a standard methodology has been established over time (see: Brown \& Warner, 1980; Bowman, 1983). This methodology is broadly applied in this study, with some differences as discussed below.

The events we analysed were the share price reaction around the announcement date of a sports sponsorship. We defined the announcement date as the effective date and denote this as $\mathrm{T}=0$. We divided the data into three sub-sets: new sponsorship announcements; renewal of an existing sponsorship; and the termination of an existing sponsorship. We also show the combined effect of the first two sub-samples (new and renewal announcements).

The daily closing share price $\left(\mathrm{P}_{\mathrm{it}}\right)$ of JSE listed companies that made public announcements relating to sports sponsorships between June 1998 and May 2011 were measured. The daily share price return $\left(\mathrm{R}_{\mathrm{it}}\right)$ was measured by:

$\mathrm{R}_{\mathrm{it}}=\ln \left[\mathrm{P}_{\mathrm{it}} / \mathrm{P}_{\mathrm{it}-1}\right]$

(Equation 1) 
The residual or abnormal return $\left(A R_{i t}\right)$ was calculated by subtracting the actual return $\left(R_{i t}\right)$ from the expected return $\left(\mathrm{K}_{\mathrm{it}}\right)$ generated by a specific benchmark:

$\mathrm{AR}_{\text {it }}=\mathrm{R}_{\mathrm{it}}-\mathrm{K}_{\mathrm{it}}$

(Equation 2)

The average abnormal return $\left(\mathrm{AAR}_{\mathrm{t}}\right)$ was then calculated by averaging the abnormal returns of all sample firms being studied in common event time:

$A A R_{t}=\frac{1}{N} \sum_{i=1}^{N} A R_{i t}$ (Equation 3)

The cumulative average abnormal return (CAAR) was then calculated by adding the average residuals from the beginning to the end of the event window.

In order to identify outliers, the individual cumulative abnormal return (CAR) of each company was compared to all the other individual CARs of the sample. Companies with CARs that deviated materially from the rest of the sample were removed from the CAAR since their behaviour was most likely influenced by a confounding event that was not part of this study.

Three benchmarks have been used in other studies in order to calculate the abnormal returns. Previous studies using the standard market model used a customised portfolio of shares (Kaul, Mehrotra \& Morck, 2000) or a simple market index (Chen, Noronha \& Singal, 2004; Shankar $\&$ Miller, 2006). A more refined methodology is to use the Capital Asset Pricing Model (CAPM) as the benchmark. This model adjusts the market return by the company's systematic risk or beta. This methodology has been used by Amihud and Mendelson (1986), Elliot, Ness, Walker \& Wan (2006) and Shankar and Miller (2006). The expected return (Kit) can be represented as follows:

$\mathrm{K}_{\mathrm{it}}=\beta \mathrm{iR} \mathrm{mt}$

(Equation 4)

Lyon, Barber \& Tsai (1999) note that the analysis of long-term abnormal returns is "treacherous" (p. 165). Therefore, an important consideration for long-term studies is the choice of benchmark against which abnormal returns are estimated. Although many event studies use the single parameter CAPM model as the benchmark, this has been shown to be inadequate. In particular, 
the CAPM fails to account for expected returns on the basis of company size as well as growth versus value (see Fama \& French, 1992, 1993, 1995, 1996, 1998) and in the South African context, a further consideration is 'resource' versus 'non-resource' shares (see van Rensburg 2001; van Rensburg \& Robertson 2003a, 2003b). Accordingly, a 12 parameter 'style' model was used to estimate benchmark returns in this study. Following Mordant \& Muller (2003), Mutooni \& Muller (2007) and Ward \& Muller (2010) twelve 'control portfolios' of shares representing the cross-sectional factors of size, growth/value and resources/non-resources were constructed and betas for each share in the sample estimated against these. Abnormal returns (ARs) for each share could then be estimated using the multiple regression equation described in Ward \& Muller (2010).

Event studies generally have abnormal return distributions that are right skewed with heavy tails (Serra, 2002). Additionally, small sample sizes cannot rely on the Central Limit Theorem for normality. Therefore a non-parametric bootstrapping procedure was used for statistical testing (Ward \& Muller, 2010). The bootstrapping procedure calculated separate daily abnormal returns for each of the shares in each sub-sample, but using dates randomly chosen within the sample time frame. A distribution from 100 montecarlo simulations of all the companies in the sample, using random dates, was generated. Bootstrap distributions were then constructed for the CAARs of each sub-sample, for each event window. The cumulative abnormal returns for each event period could then be measured against this distribution to test for significance.

\section{Results}

Appendix 1 presents a complete list of sponsorship announcements analysed, including details of the firm, industry, sport, and type of announcement. The majority of announcements analysed were new sponsorships (58\%), followed by renewal announcements $(25 \%)$ and termination announcements (16\%). The banking industry contained almost half the number of firms (49\%). In terms of sport being sponsored, football (soccer) represented the largest number (46\%), followed by rugby $(17 \%)$.

A pre-event window period of 100 trading days prior to the announcement date was used; and a post-event window of 120 trading days after the announcement data was used. Figure 1 presents the results of the event study. 
[Insert Figure 1 about here]

In analysing Figure 1 it should be noted that the sample sizes were small, particularly the sample of announcements relating to sponsorships which were terminated. However, we observe the following:

Over the full event window, the samples of new and renewed sponsorship announcements follow a similar pattern to each other, and for parsimony these are combined and shown as the bold line. In the 100 days prior to the announcement we observe the cumulative abnormal returns steadily decline by around 3\%. There appears to be a small (but insignificant) reversal of the decline at the event date (and for a few days following). In the post event period it is apparent that the steady decline observed in the pre-event window has not reversed, but has merely stabilised at about $99 \%$ of the value at the event date.

The sample containing companies in which a sponsorship was terminated exhibits a much more volatile pattern, largely on account of the small sample size. Over the pre-event period T100 to T-60 we note a rapid appreciation in value from $95 \%$ to $102 \%$. Over the period T-60 to $\mathrm{T}+40$ the CAARs are volatile but stable. From $\mathrm{T}+40$ to $\mathrm{T}+100$ we observe a steady decline in value of about $4 \%$.

Figure 2 below presents the results of the randomised sample from which the bootstrap distributions were generated. We use the same companies (repeated five times, to increase the sample size) but with randomly generated event dates.

[Insert Figure 2 about here]

In Figure 2 we observe, as expected, much more stable patterns in the CAARs. In each of the samples no trend is evident, and the CAARs remain constant in value. The sample of terminated sponsorships exhibits more volatility than the other groups.

[Insert Table 1 about here] 
In the case of new sponsorship announcements there are no significant findings (see Table 1). For renewal sponsorship announcements we observe that the CAARs at T-100 are positive and significant. The positive sign indicates that these companies were trading about $5 \%$ higher than their benchmark, and that over the 100 trading days (i.e. about 6 months) prior to the announcement date they lost relative value. In the 20 days post the announcement $(\mathrm{T}+20)$ these companies appear to have benefited by almost 5\% from their renewed sponsorship, but the gain is short lived and insignificant by $\mathrm{T}+100$. For companies which terminated their sponsorship we observe a significant result at T-100. Over the 100 trading days (i.e. about 6 months) prior to the announcement date they gained around 5\% in relative value. After the announcement there is no significant effect.

\section{Discussion}

The data analysed found no significant share price increases or decreases for new and termination sponsorship announcements. The findings demonstrated a short-term increase of $4.35 \%$ for renewal announcements. The results suggest that investors largely did not take sponsorship announcements into account when assessing the future profitability of these firms. These findings provide further caution to the accepted view that the marketplace sees sponsorships as a good investment (Cornwell, Pruitt \& Clark, 2005). The lack of support reported for the first hypothesis related to first-time sponsorships reinforces the findings of Ozturk, Kozub and Kocak (2004) and Clark, Cornwell and Pruitt (2009). The initial positive share price reaction finding related to Hypothesis Two supports the results of Clark, Cornwell and Pruitt's (2009) NASCAR renewal announcements, and contributes additional data to this important question. Importantly, the short-term increase finding suggests that the impact of a renewal announcement may not provide a positive impact beyond 20 trading days, which was also the period measured in Clark, Cornwell and Pruitt's (2009) study. Our finding of no share price impact from sponsorship termination announcements provides some initial guidance related to hypothesis three. Given the lack of market response to these statements of sponsorship withdrawal, the research provides further context to Copeland, Frisby and McCarville's (1996) reasons for sponsorship nonrenewal. 
Amis, Slack and Berrett (1999) argued that a sport sponsorship should be assessed in terms of its potential to contribute to a position of competitive advantage for the firm. The authors recommended that achieving this would require committing time, effort and resources to it, similar to other investments that are expected to generate positive future shareholder wealth. Our findings suggest that, although some firms may express such sentiments in their new, renewal and termination sponsorship announcements, these are not always taken into account by the market. Absa Bank's announcement of their official team sponsorship of the Springbok rugby team may be instructive. Absa, a subsidiary of Barclays Bank plc, issued a media release at 16:31 on Thursday, 3 February 2011, in which the Group Chief Executive Maria Ramos stated: "As a leading financial services brand, we view our sponsorships as powerful vehicles that enable us to communicate and connect with consumers from all walks of life... Sponsorships are a cornerstone of our marketing investment, and our brand is one of our most cherished and important corporate assets" (Bridgraj, 2011). Although this statement suggested that the estimated US\$34 million sponsorship was core to the firm's strategy to acquire, grow and retain more profitable customers, the news was not covered in the firm's Stock Exchange News Service (SENS) announcements on 31 January or 15 February. Companies are required to make announcements to shareholders of any "material issues" (Ward \& Muller, 2010, p. 29) which may impact share prices through SENS. As a result, it is possible that the announcement was not instantly observable as an unambiguous signal (Johnston, 2010) to the market of current and long-term economic performance.

Clark, Cornwell and Pruitt (2009) explained their finding of no share price impact of title sponsorship announcements by suggesting that investors calculated the returns due to firms as a result of the sponsorship as equal to the prices paid. The authors rejected the possibility of inattention on the part of investors. In this way, Clark, Cornwell and Pruitt (2009) argued that a firm would accept a sponsorship seen as an investment with a zero net present value. This alternate explanation for our findings suggests that investors evaluated sponsorship contracts as achieving market-clearing prices, driven by a competitive market and rigorous negotiations. This may have been the case with Nedbank's five-year estimated US\$55 million sponsorship of the Premier Soccer League's Nedbank Cup in November 2007. Media reports suggested that the firm had "outbid five other companies for the rights" (Anonymous, 2007, p. 1), while Nedbank's group strategy and corporate affairs director Nombulelo Moholi said: "The announcement of the 
Nedbank Cup sponsorship marks the culmination of a long search by Nedbank for an appropriate, and significant, opportunity to support the soccer fraternity and extend the brand building and marketing programmes that have been so successful for us in road running, golf and sport for people with disabilities" (Anonymous, 2007, p. 1).

An alternate explanation for our broadly neutral impact findings is the size or importance of sponsorship contracts relative to other investments made by the sponsoring firms. For the financial services firms in our sample, investors may be "moved" by announcements of multimillion dollar branch infrastructure or technology platform investments. Announcements of more moderate investments aimed at sports fans may not convey information that is value-relevant to the firm's future performance (Johnston, 2010), a suggestion that is also highlighted below as an opportunity for further research. Another example was Sasol in 2004, whose estimated US\$20 million investment in SA Rugby may have been overshadowed by the almost 50 times larger US\$950 million Gas-to-Liquid Oryx Plant in Qatar and the rollout of 146 Sasol Convenience Centres (Sasol, 2006).

For sponsoring firms, our findings provide further caution to the conventional view that announcements of new, renewal or terminated sponsorship agreements always provide shortterm positive or negative impacts on share price returns. The results point to the lack of consideration given to the sponsorship investment by investors. The findings suggest that managers need to reconsider their communication efforts to more effectively signal the strategic nature of sport sponsorships.

\section{Limitations and further research}

There are several limitations to this study. First, our study only drew on publicly available sponsorship announcement and share price data. A more complete analysis could be undertaken to integrate the decision-criteria employed by investors in these firms. Additional qualitative data gathering and analysis related to the periods following each sponsorship announcement could help determine the extent to which sponsorship announcements are considered by investors.

In addition, research including other possible variables could contribute to a greater understanding of the conditions under which share price returns are impacted. Our research considered the type of sport sponsored and the industry of the sponsoring firm. Further research 
could determine whether the stock market listing of firms matters. This avenue may be appealing given the increasing number of dual-listed firms, especially from emerging markets. Another variable to consider in further share price impact studies is the size of the sponsorship agreement, relative to the firm's marketing spend (Jensen \& Hsu, 2011), as suggested by the alternate explanation for our neutral impact findings above. Finally, further research across multiple industries could investigate any differences between business-to-business marketing and business-to-consumer marketing strategies.

Previous studies of the share price impact of sponsorship announcements have typically included smaller numbers of events. Although our research drew on one of the larger samples investigated, a more extensive study of sponsors listed on other non-USA stock exchanges, including Brazil and India, could also be in the offing. 


\section{References}

Amihud, Y., \& Mendelson, H. (1986) Asset pricing and the bid-ask spread. Journal of Financial Economics, 17(2), 223-249.

Amis, J., Slack, T., \& Berrett, T. (1999) Sport sponsorship as distinctive competence. European Journal of Marketing, 33(3/4), 250-272.

Anonymous. (2007) Nedbank agrees Premier Soccer League deal. Retrieved from: http://www.sportbusiness.com/news/162952/nedbank-agrees-premier-soccer-league-deal.

Becker-Olsen, K. (2003) Questioning the Name Game: An Event Study Analysis of Stadium Naming Rights Sponsorship Announcements. Journal of Sports Marketing \& Sponsorship, 5(3), 181-192.

Bidgraj, A. (2011) New sponsor Absa scrums down with the Springboks. Retrieved from: http://www.link2media.co.za/index.php?option=com_content\&task=view\&id=11039\&Itemid=1 2.

Bowman R. (1983) Understanding and conducting event studies. Journal of Business and Financial Accounting, 10(4): 561-584.

Brown S., \& Warner J. (1980) Measuring security price performance. Journal of Financial Economics, 8, 205-258.

Chen, H., Noronha, G., \& Singal, V. (2004) The price response to S\&P 500 index additions and deletions: Evidence of asymmetry and a new explanation. Journal of Finance, 59(4), 1901-1929.

Clark, J.M., Cornwell, T.B., \& Pruitt, S.W. (2002) Corporate stadium sponsorship, signalling theory, agency conflicts and shareholder wealth. Journal of Advertising Research, 42, 16-32. 
Clark, J.M., Cornwell, T.B. \& Pruitt, S.W. (2009) The impact of title event sponsorship announcements on shareholder wealth. Marketing Letters, 20, 169-182.

Copeland, R., Frisby, W., \& McCarville, R. (1996) Understanding the sport sponsorship process from a corporate perspective. Journal of Sport Management, 10, 32-48.

Cornwell, T.B. (2008) State of the art and science in sponsorship-linked marketing. Journal of Advertising, 37(3), 41-55.

Cornwell, T.B., Pruitt, S.W. \& Clark, J.M. (2005) The relationship between major-league sports' official sponsorship announcements and the stock prices of sponsoring firms. Journal of the Academy of Marketing Science, 33, 401-412.

Crimmins, J. \& Horn, M. (1996) Sponsorship: from management ego trip to marketing success. Journal of Advertising Research, 36, 11-21.

Daellenbach, K., Davies, J., \& Ashill, N.J. (2006) Understanding sponsorship and sponsorship relationships - multiple frames and multiple persepctives. International Journal of Nonprofit and Voluntary Sector Marketing, 11(1), 73-87.

Elliott, W.B., Ness, B.F.V., Walker, M.D., \& Wan, R.S. (2006) What drives the S\&P 500 inclusion effect? An analytical survey. Financial Management, 35(4), 31-48.

Fama, E.F. (1991) Efficient Capital Markets: II. The Journal of Finance, 46(5), 1575-1617.

Fama, E., \& French, K. (1992) The Cross-Section of Expected Stock Returns. Journal of Finance, 47(2), 427-465.

Fama, E., \& French, K. (1993) Common Risk Factors in the Returns of Stocks and Bonds. Journal of Financial Economics, 53, 427-465. 
Fama, E., \& French, K. (1995) Size and Book to Market Factors in Earnings and Returns. Journal of Finance, 50, 131-155.

Fama, E., \& French, K. (1996) Multifactor explanations of asset pricing anomalies. Journal of Finance, 51, 55-84.

Fama, E., \& French, K. (1998) Value versus Growth: The International Evidence. Journal of Finance, 53, 1975-1999.

Farrelly, F. (2010) Not playing the game: Why sport sponsorship relationships break down. Journal of Sport Management, 24, 319-337.

Filbeck, G., Zhao, X., Tompkins, D., \& Chong, P. (2009) Share price reactions to advertising announcements and broadcast of media events. Managerial and Decisions Economics, 30, 253 264.

Formula1.com. (2010) Vodafone's Daragh Persse on the value of the F1 sponsorship. Retrieved from: http://www.formula1.com/news/interviews/2011/8/12414.html.

Goldman, M.M. (2011) Post-Crisis Sports Marketing Business Model Shifts. Managing Global Transitions, 9(2), 171-184.

Gumede, R. (2011) Where to for Lions Rugby. Retrieved from:

http://www.moneyweb.co.za/mw/view/mw/en/page330502?oid=524855\&sn=2009+Detail\&pid= 295683.

IEG. (International Event Group) (2011) Sponsorship spending: 2010 proves better than expected; bigger gains set for 2011. IEG Sponsorship Report. Chicago: IEG, Inc.

Jensen, J.A. \& Hsu, A. (2011) Does sponsorship pay off? An examination of the relationship between investment in sponsorship and business performance. International Journal of Sports 
Marketing \& Sponsorship, 12(4), 352-364.

Johnston, M.A. (2010) The impact of sponsorship announcements on shareholder wealth in Australia. Asia Pacific Journal of Marketing and Logistics, 22(2), 156-178.

Kaul, A., Mehrotra, V., \& Morck, R. (2000) Demand curves for stocks do slope down: New evidence from an index weights adjustment. The Journal of Finance, 55(2), 893-912.

Kim, J. (2010) The worth of sport event sponsorship: An event study. Journal of Management and Marketing Research, 5, 1-14.

Kim, J. \& Morris, J.D. (2003) The effect of advertising on the market value of firms: Empirical evidence from the Super Bowl ads. Journal of Targeting, Measurement and Analysis for Marketing, 12(1), 53-65.

Lei, S., Ghosh, C., \& Srinivasan, H. (2010) Should they play? Market value of corporate partnerships with professional sport leagues. Journal of Sport Management, 24, 702-743.

Li, M., Sparks, R., \& Yang, X.S. (2008) Sports sponsorship as a strategic investment in China: perceived risks and benefits by corporate sponsors prior to the Beijing 2008 Olympics. International Journal of Sports Marketing \& Sponsorships, 10(1), 63-78.

Lyon, J.D., Barber, B.M., \& Tsai, C. (1999) Improved methods for tests of long-run abnormal stock returns. The Journal of Finance, 54(1), 165-201.

Mason, R.B. \& Cochetel, F. (2006) Residual brand awareness following the termination of a long-term event sponsorship and the appointment of a new sponsor. Journal of Marketing Communications, 12(2), 125-144.

McWilliams, A. \& Siegel, D. (1997) Event studies in management research: theoretical and empirical issues. Academy of Management Journal, 40(3), 626-657. 
Mishra, D.P., Bobinski, G.S., Bhabra, H.S. (1997) Assessing the Economic Worth of Corporate Event Sponsorships: A Stock Market Perspective. Journal of Market Focused Management, 2, 149-169.

Miyazaki, A.D. \& Morgan, A.G. (2001) Assessing market value of event sponsoring: corporate Olympic sponsorships. Journal of Advertising Research, 41, 9-13.

Mordant N., \& Muller C. (2003) Profitability of director's share dealings on the JSE. Investment Analysts Journal, 57, 17-32.

Mutooni R., \& Muller C. (2007) Equity Style Timing. Investment Analysts Journal, 65, 15-24.

Orphanides, S. (2010) Standard Bank 'moving forward' with more efficient marketing. Retrieved from http://www.moneyweb.co.za/moneyweb-radio-business-of-sport/standard-bank-moving forward-with-more-efficient-2

Ozturk, M.A., Kozub, F.M., \& Kocak, S. (2004) Impact of sponsorship on companies that supported the 2002 Salt Lake City Winter Paralympics. International Journal of Sports Marketing \& Sponsorship, 5(4), 282-295.

Pruitt, S., Cornwell, T.B. \& Clark, J. (2004) The NASCAR phenomenon: auto racing sponsorships and shareholder wealth. Journal of Advertising Research, 44, 281-296.

Roy, D.P. \& Cornwell, T.B. (2003) Brand equity’s influence on responses to event sponsorships. Journal of Product and Brand Management, 12(6), 377-393.

Sasol. (2006) Annual Review 2005. Retrieved from:

http://sasol.quickreport.co.za/sasol_ar_2005/commentary.

Scarcella, E. (2010) Enzo Scarcella on Vodacom's investment in sport. Retrieved from: 
http://www.moneyweb.co.za/mw/view/mw/en/page330502?oid=479651\&sn=2009\%20Detail.

Serra, A.P. (2002) Event study tests: A brief survey. Working Papers Da FEP no. 117

Shankar, S.G., \& Miller, J.M. (2006) Market reaction to changes in the S\&P SmallCap 600 index. Financial Review, 41(3), 339-360.

Smolianov, P. \& Shilbury, D. (2005) Examining integrated advertising and sponsorship in corporate marketing through televised sport. Sport Marketing Quarterly, 14(4), 239-250.

Spais, G.S. \& Filis, G.N. (2008) Measuring stock market reaction to sponsorship announcements: The case of Fiat and Juventus. Journal of Targeting, Measuring \& Analysis for Marketing, 16(3), 169-180.

Sport Marketing Frontiers. (2011) Report: Country by ranking. Retrieved from: http://frontiers.sportbusiness.com.

Van Rensberg, P. (2001) A decomposition of style-based risk on the JSE. Investment Analysts Journal, 54, 45-60.

Van Rensburg, P., \& Robertson, M. (2003a) Style Characteristics and the Cross-section of JSE Returns. Investments Analysts Journal, 57, 1-10.

Van Rensburg, P., \& Robertson, M. (2003b) Size, Price to Earnings and Beta on the JSE. Investments Analysts Journal, 58, 1-11.

Ward, M. \& Muller, C. (2010) The long-term share price reaction to Black Economic Empowerment announcements on the JSE. Investment Analysts Journal, 71, 27-36. 